\title{
Studies on Heterosis and Inbreeding Depression for Quality Traits and Yield in Tomato (Solanum lycopersicum L.)
}

\author{
M. Sunil Kumar ${ }^{*}$, A. K. Pal ${ }^{2}$ and Anil K. Singh ${ }^{2}$ \\ '(Horticulture), PJTSAU, Hyderabad, Telangana, India \\ ${ }^{2}$ Institute of Agricultural Sciences, BHU, Varanasi, India \\ *Corresponding author
}

\section{A B S T R A C T}

\begin{tabular}{|l|}
\hline Ke y w o r d s \\
$\begin{array}{l}\text { Quality traits and } \\
\text { yield, hybrid, heterotic } \\
\text { effects, inbreeding } \\
\text { depression }\end{array}$ \\
\hline Article Info \\
\hline $\begin{array}{l}\text { Accepted: } \\
\text { 25 May } 2018 \\
\text { Available Online: } \\
\text { 10 June 2018 }\end{array}$ \\
\hline
\end{tabular}

Thirteen parental lines along with their 30 hybrid combinations produced by crossing in Line $\times$ Tester mating design were evaluated for heterosis and inbreeding depression of fruit quality traits and yield viz., total soluble solids (TSS), titratable acidity, ascorbic acid, fruit $\mathrm{pH}$, lycopene, total sugars, reducing sugars, non-reducing sugars and total yield per plant. Highest heterotic effects for quality traits and yield over standard checks (SH1 and $\mathrm{SH} 2$ ) was observed for total yield per plant $(\mathrm{kg})$ followed by titrable acidity $(\%)$, ascorbic acid $(\mathrm{mg} / 100 \mathrm{~g})$, total soluble solids ( ${ }^{\circ}$ Brix) and lycopene content $(\mathrm{mg} / 100 \mathrm{~g})$. Inbreeding depression was also observed for different cross combinations. The crosses with significant heterosis in $\mathrm{F}_{1}$ could be used for the improvement of tomato for quality traits and yield.

\section{Introduction}

Tomato is one of the most commercially important vegetables which is grown widely throughout the world. It has variety of uses such as for cooking, as salad and in making variety of processed products. Fruit quality envisages shape, size and colour along with sensory attributes like taste, acidity and sugars. Tomato ripening is of interest to breeders as it affects several quality traits like colour, flavor and total soluble solids (TSS). Shelf life is another important attribute for fresh market tomatoes. The colour of skin and flesh determine the red colour in tomato (Bai and Lindhout, 2007).
The colour variation ranges from yellow to colourless for skin colour and for flesh colour it varied between red and green. The level of lycopene is increased by 500 fold during ripening. Lycopene is a powerful antioxidant which is associated with the reduction of certain forms of cancer (Miller et al., 2012). Flavour is the sum of the interaction between sugars, acids and a set of approximately 30 volatile compounds (Tieman et al., 2006).

Inspite of being a self-pollinated crop, tomato has tremendous potential for heterosis breeding. The hybrid vigour is being exploited commercially because of several advantages in hybrids over purelines. Choice 
of parents is of prime importance for exploitation of heterosis.

\section{Materials and Methods}

Thirty crosses were done between 10 genotypes as lines and 3 genotypes as testers in Line $\times$ Tester mating design. Lines were used as females and testers as males. The experiment was carried out during 2012-2013 and 2013-14 at Vegetable Research Farm, Institute of Agricultural Sciences, Banaras Hindu University, Varanasi (Uttar Pradesh). During Rabi, 2012 the nursery grown seedlings of 10 lines and 3 testers were transplanted in separate crossing block and 30 cross combinations were made. Parental populations and F1's were evaluated during Kharif, 2013. F1's, F2's along with parents were raised in Rabi, 2013 to know the inbreeding depression in tomato. During evaluation 30 cross combinations, 13 parents and 2 standard checks ( $\mathrm{SH} 1$ and $\mathrm{SH} 2$ ) were grown in three replications using Randomized block design (RBD).

All the intercultural operations were carried out in accordance with recommended package of practices from time to time. Quality traits and yield were evaluated viz., total soluble solids (TSS), titratable acidity, ascorbic acid, fruit $\mathrm{pH}$, lycopene, total Sugars, reducing sugars, non-reducing sugars and total yield per plant. Analysis of variance (ANOVA) for design of experiment was carried out following Panse and Sukhatme (1967). The significance of differences among treatment means (parent and hybrids) was tested by ' $\mathrm{F}$ test'. ANOVA for testing the differences among progenies and parents (line $\times$ tester) was done using standard procedure given by Singh and Chaudhary (1979).

\section{Results and Discussion}

The analysis of variance for line $x$ tester mating design for 10 genotypes as lines (Arka
Meghali, Punjab Upma, BT-12, Floradade, H86, H-24, Sel-7, PS-1, Fla-7171 and Azad T$5)$ and three genotypes testers (H-88-78-4, DT-2 and Pant T-3) and 30 crosses was done. The source of variation showed positive significance for all the characters between treatments. Standard heterosis over first check (SH1) and second check (SH2) were presented (Table 1) along with inbreeding depression for top three crosses. For total soluble solids highest positive standard heterosis was observed for cross $\mathrm{H}-86 \times \mathrm{H}-$ 88-78-4 (49.44) over first check and for cross H-86 $\times$ H-88-78-4 (55.37) over second check.

These results are in line with the reports from Rattan (2007), Kumar et al., (2013), Shalaby (2013) and Kumar and Paliwal (2016). For titratable acidity, the crosses PS- $1 \times \mathrm{H}-88-78$ 4 (58.17) and PS-1 $\times$ H-88-78-4 (67.47) showed maximum positive heterosis over first check and second check respectively. These results are in accordance with the findings of Joshi et al., (2005), Rattan (2007) and Kumar et al., (2006).

For ascorbic acid highest positive heterosis over better parent was found in cross PS- $1 \times$ DT-2 (36.10) over first check and in cross PS$1 \times$ DT-2 (44.72) over second check.

These results are in line with the reports from Duhan et al., (2005) and Kumar et al., (2013). For fruit $\mathrm{pH}$, highest positive heterosis over first check and second check was recorded in crosses PS-1 $\times$ Pant T-3 (-25.48) and PS-1 $\times$ Pant T-3 (-27.71) respectively.

These results are in consonance with the findings of Tendulkar (1994) and Patil (1997). For lycopene content highest positive heterosis was observed in cross $\mathrm{H}-24 \times$ Pant T-3 (37.67) over first check and $\mathrm{H}-24 \times$ Pant T-3 (25.65) over second check. These results are in line with the reports from Kumar et al., (2006) and Kumar and Paliwal (2016). 
Table.1 Standard heterosis and inbreeding depression for quality traits and yield in tomato

\begin{tabular}{|c|c|c|c|c|c|}
\hline \multirow[t]{2}{*}{ S.No. } & \multirow[t]{2}{*}{ Character } & \multirow[t]{2}{*}{ Top cross combinations } & \multicolumn{2}{|c|}{$\begin{array}{l}\text { Standard Heterosis over } \\
\text { hydrid checks SH1 and } \\
\text { SH2 }\end{array}$} & \multirow[t]{2}{*}{ Inbreeding depression } \\
\hline & & & SH1 & SH2 & \\
\hline \multirow[t]{3}{*}{1.} & \multirow{3}{*}{$\begin{array}{l}\text { Total soluble } \\
\text { solids }\left({ }^{\circ} \text { Brix }\right)\end{array}$} & $\mathrm{H}-86 \times \mathrm{H}-88-78-4$ & 49.44 & 55.37 & \multirow{3}{*}{$\begin{array}{l}\text { H-86 } \times \text { H-88-78-4 (8.83) } \\
\text { H-24 × Pant T-3 (7.23) } \\
\text { Arka Meghali } \times \text { Pant T-3 }(6.73)\end{array}$} \\
\hline & & Azad T-5 × H-88-78-4 & 37.75 & 43.22 & \\
\hline & & Arka Meghali × H-88-78-4 & 33.71 & 39.02 & \\
\hline \multirow[t]{3}{*}{2.} & \multirow{3}{*}{$\begin{array}{l}\text { Titrable acidity } \\
(\%)\end{array}$} & PS- $1 \times \mathrm{H}-88-78-4$ & 58.17 & 67.47 & \multirow{3}{*}{$\begin{array}{l}\text { Arka Meghali } \times \text { H-88-78-4 (14.26) } \\
\text { Arka Meghali } \times \text { Pant T-3 }(8.98) \\
\text { Fla-7171 } \times \text { H-88-78-4 }(7.76)\end{array}$} \\
\hline & & Arka Meghali × H-88-78-4 & 49.50 & 58.29 & \\
\hline & & BT- $12 \times \mathrm{H}-88-78-4$ & 49.50 & 58.29 & \\
\hline \multirow[t]{3}{*}{3.} & \multirow{3}{*}{$\begin{array}{l}\text { Ascorbic acid } \\
(\mathrm{mg} / 100 \mathrm{~g})\end{array}$} & PS-1 $\times$ DT-2 & 36.10 & 44.72 & \multirow{3}{*}{$\begin{array}{l}\text { H-86 × H-88-78-4 (8.63) } \\
\text { H-24 × DT-2 (5.71) } \\
\text { Fla-7171 × DT-2 (4.66) }\end{array}$} \\
\hline & & Floradade $\times$ Pant $T-3$ & 21.48 & 29.17 & \\
\hline & & BT-12 $\times$ Pant T-3 & 17.78 & 25.24 & \\
\hline \multirow[t]{3}{*}{4.} & \multirow[t]{3}{*}{ Fruit $\mathrm{pH}$} & PS- $1 \times$ Pant T- 3 & -25.48 & -27.71 & \multirow{3}{*}{$\begin{array}{l}\text { Punjab Upma } \times \text { DT-2 }(-4.43) \\
\text { Sel-7 } \times \text { Pant T-3(-4.25) } \\
\text { PS-1 } \times \text { DT-2 }(-4.12)\end{array}$} \\
\hline & & $\mathrm{H}-24 \times \mathrm{DT}-2$ & -13.28 & -15.89 & \\
\hline & & Sel-7 $\times$ Pant T-3 & -13.10 & -15.7 & \\
\hline \multirow[t]{3}{*}{5.} & \multirow{3}{*}{$\begin{array}{l}\text { Lycopene } \\
\text { content } \\
(\mathrm{mg} / 100 \mathrm{~g})\end{array}$} & $\mathrm{H}-24 \times$ Pant T-3 & 37.67 & 25.65 & \multirow{3}{*}{$\begin{array}{l}\text { H-86 } \times \text { Pant T-3 }(6.85) \\
\text { BT-12 } \times \text { Pant T-3 }(6.66) \\
\text { Sel-7 } \times \text { Pant T-3 }(5.94)\end{array}$} \\
\hline & & Sel-7 $\times$ Pant T-3 & 36.42 & 24.51 & \\
\hline & & BT- $12 \times$ Pant T- 3 & 36.11 & 24.23 & \\
\hline \multirow[t]{3}{*}{6.} & \multirow{3}{*}{$\begin{array}{l}\text { Total Sugars } \\
(\%)\end{array}$} & BT- $12 \times$ H-88-78-4 & 12.21 & 17.08 & \multirow{3}{*}{$\begin{array}{l}\text { Arka Meghali } \times \text { Pant T-3 (4.28) } \\
\text { PS- } 1 \times \text { H-88-78-4 (4.21) } \\
\text { H- } 86 \times \text { DT-2 }(3.93)\end{array}$} \\
\hline & & Sel-7 $\times$ H-88-78-4 & 8.03 & 12.72 & \\
\hline & & Arka Meghali × H-88-78-4 & 6.48 & 11.09 & \\
\hline \multirow[t]{3}{*}{7.} & \multirow{3}{*}{$\begin{array}{l}\text { Reducing } \\
\text { sugars }(\%)\end{array}$} & BT-12 × H-88-78-4 & 16.90 & 21.28 & \multirow{3}{*}{$\begin{array}{l}\text { H- } 86 \times \text { DT-2 }(5.15) \\
\text { PS- } 1 \times \text { H-88-78-4 (5.11) } \\
\text { BT- } 12 \times \text { H-88-78-4 }(5.00)\end{array}$} \\
\hline & & Sel-7 $\times$ H-88-78-4 & 14.46 & 18.75 & \\
\hline & & Fla-7171 × H-88-78-4 & 13.39 & 17.64 & \\
\hline \multirow[t]{3}{*}{8.} & \multirow{3}{*}{$\begin{array}{l}\text { Non-Reducing } \\
\text { sugars }(\%)\end{array}$} & Arka Meghali × H-88-78-4 & 5.36 & 11.32 & \multirow{3}{*}{$\begin{array}{l}\text { H-24 × Pant T-3 }(3.93) \\
\text { H-86 × Pant T-3 }(2.90) \\
\text { Azad T-5 } \times \text { Pant T-3 }(2.48)\end{array}$} \\
\hline & & BT-12 × H-88-78-4 & 1.79 & 7.55 & \\
\hline & & Azad T-5 $\times$ H-88-78-4 & 1.79 & 3.77 & \\
\hline \multirow[t]{3}{*}{9.} & \multirow{3}{*}{$\begin{array}{l}\text { Total yield per } \\
\text { plant }(\mathrm{kg})\end{array}$} & Azad T-5 $\times$ DT-2 & 62.46 & 30.84 & \multirow{3}{*}{$\begin{array}{l}\text { Azad T-5 × DT-2 (24.09) } \\
\text { Sel-7 × DT-2 (18.27) } \\
\text { Azad T-5 × Pant T-3 }(16.42)\end{array}$} \\
\hline & & Sel-7 $\times$ DT -2 & 56.08 & 25.7 & \\
\hline & & Punjab Upma $\times$ DT-2 & 50.76 & 21.42 & \\
\hline
\end{tabular}

For total sugars, the cross BT-12 $\times$ H-88-78-4 (12.21) and BT-12 $\times$ H-88-78-4 (17.08), showed maximum standard heterosis over first check and second check in respectively. For reducing sugars highest positive heterosis was observed for cross BT-12 $\times \mathrm{H}-88-78-4$ (16.90) over first check and BT-12 $\times$ H-8878-4 (21.28) over second check. These results are in line with the reports from Gul et al., (2013). For non-reducing sugars maximum standard heterosis over first check and second check was observed in crosses Arka Meghali $\times \mathrm{H}-88-78-4$ (5.36) and Arka Meghali $\times \mathrm{H}-$ 88-78-4 (11.32). For total yield per plant, maximum positive heterosis over first check and second check was maximum in Azad T-5 $\times$ DT-2 (62.46) and Azad T-5 × DT-2 (30.84) respectively. These results are in accordance with the findings of Chauhan et al., (2014), Aisyah et al., (2016) and Savale et al., (2017).

The hybrid vigour expressed in $F_{1}$ usually breaks down in $\mathrm{F}_{2}$ and later generations due to segregation of the favourable genes that govern the expression of the vigour. As a result, there is generally a decrease in the yield. To estimate decline in the performance of hybrid, the extent of inbreeding depression was recorded for the various characters. Top three crosses showing maximum inbreeding 
depression for all the characters in the present study are presented in Table 1. Highest inbreeding depression was observed in crosses Azad T-5 $\times$ DT-2 (24.09) for total yield per plant $(\mathrm{kg}), \mathrm{H}-86 \times \mathrm{H}-88-78-4(8.83)$ for total soluble solids (\%), Arka Meghali $\times$ H-88-78-4 (14.26) for titratable acidity $(\mathrm{mg} / 100 \mathrm{~g}), \mathrm{H}-86 \times \mathrm{H}-88-78-4$ (8.63) for ascorbic acid $(\mathrm{mg} / 100 \mathrm{~g})$, Punjab Upma $\times$ DT-2 (-4.43) for fruit $\mathrm{pH}, \mathrm{H}-86 \times$ Pant T-3 (6.85) for lycopene content (mg/100 g), Arka Meghali $\times$ Pant T-3 (4.28) for total Sugars (\%),H-86 $\times$ DT-2 (5.15) for reducing sugars (\%) and H-24 $\times$ Pant T-3 (3.93) for nonreducing sugars $(\%)$.

It is inferred from the results that crosses showing higher estimates of heterosis exhibited high inbreeding depression. This might be due to presence of non-additive gene action for the characters under study. However, some crosses showed high heterosis with low inbreeding depression. This might be due to presence of large number of transgressive segregants in the $\mathrm{F}_{2}$ generation. These results are in conformity with the findings of Patel et al., (2010), Nosser (2012) and Dagade et al., (2015).

\section{References}

Aisyah, S.I., Wahyuni, S., Syukur, M. and Witono, J.R. 2016.The Estimation of Combining Ability and Heterosis Effect for Yield and Yield Components in Tomato (Solanum lycopersicum Mill.) at Lowland. Ekin Journal of Crop Breeding and Genetics. 2(1): 23-29.

Bai, Y. and Lindhout, P. 2007. Domestication and Breeding of Tomatoes: What have We Gained and What Can We Gain in the Future? Annals of Botany. 100(5): 1085-1094.

Chauhan, V. B. S., Kumar, R., Behera, T. K. and Yadav, R. K. 2014.Studies on Heterosis for yield and its Attributing
Traits in Tomato (Solanumlycopersicum L.). International Journal of Agriculture Environment and Biotechnology. 7(1): 95-100.

Dagade, S. B., Barad, A. V., Dhaduk, L. K., and Hariprasanna,, K. 2015. Estimates of hybrid vigour and inbreeding depression for fruit nutritional characters in tomato. International Journal of Science Environment and Technology. 4(1): 114-124.

Duhan, D., Partap, P. S., Rana, M. K. and Basawana, K. S. 2005. Study of heterosis for growth and yield characters in tomato. Haryana Journal of Horticultural Sciences. 34(1): 366370.

Gul, R., Rahman, H., Tahir, M,„Naeem, M. and Ghafoor, A. Estimates of heterosis for morphological and flavor attributes in tomato. International Journal of Vegetable Science. 19(3): 256-262. 2013.

Joshi, A., Thakur, M. C. and Kohli, U. K. 2005. Heterosis and combining ability for shelf-life, whole fruit firmness and related traits in Tomato. Indian Journal of Horticulture. 62(1): 101-103.

Kumar, P. and Paliwal, A. 2016. Heterosis breeding for quality improvement in hybrids to be developed specifically for garhwal hills in tomato (Lycopersicon esculentum Mill.). International Journal of Science and Research. 5(11): 356359.

Kumar, R., Mishra, N.K., Singh, J., Rai, G.K., Verma, A. and Rai, M. 2006. Studies on yield and quality traits in tomato (Solanum lycopersicon (Mill.) Wettsd.). Veg. Sci., 33: 126-132.

Kumar, R., Srivastava, K., Singh, N. P., Vasistha, N. K., Singh, R. K. and Singh, M. K. 2013. Combining ability analysis for yield and quality traits in tomato (Solanum lycopersicum L.). Journal of Agricultural Sciences, 5(2): 213-218. 
Kumar, R., Srivastava, K., Singh, N. P., Vasistha, N. K., Singh, R. K. and Singh, M. K. 2013. Combining ability analysis for yield and quality traits in tomato (Solanum lycopersicum L.). Journal of Agricultural Sciences, 5(2): 213-218.

Miller, E.C., Hadley, C.W., Schwartz, S.J., Erdman, J.W., Boileau, T.W.M., Clinton, S.K. 2002. Lycopene, tomato products and prostate cancer prevention. Have we established causality? Pure and Applied Chemistry, 74: 1435-1441.

Nosser, M.A. 2012. Heterosis and inbreeding depression in tomato. Egyptian Journal of Plant Breeding, 16(1): 1-17.

Panse, V.G. and Sukhatme, P.V. 1967. Statistical Methods for Agricultural Workers. Indian Council of Agricultural Research, New Delhi. p.381,

Patel, U.J., Kathiria, K.B., Patel, J.S. and Saiyad, I.M. 2010. Heterobeltiosis and inbreeding depression in tomato (Lycopersicon esculentum Mill.). International Journal of Plant Sciences, 5:2, 636-638.

Patil, G.S. 1997. Genetic analysis and economic usage of compound inflorescence in tomato. Ph.D. Thesis, University of Agricultural Sciences, Dharwad.

Rattan, P. 2007. Line $\times$ Tester analysis involving bacterial wilt resistant genotypes across environments in tomato (Lycopersicon esculentum Mill.). Ph.D. Thesis, pp 248, Department of Vegetable Science and Floriculture, CSK Himachal Pradesh, Krishi Vishvavidyalaya, Palampur176062 (HP), India.

Savale, S. V., Patel, A. I. and Sante, P. R. 2017. Study of heterosis over environments in tomato (Solanum lycopersicum L.). International Journal of Chemical Studies, 5(3): 284-289.

Shalaby, T. A. 2013. Mode of gene action, heterosis and inbreeding depression for yield and its components in tomato (Solanum lycopersicum L.). Scientia Horticulturae, 16(4): 540-543.

Singh, R. H. and Chaudhary, B. D. 1979. Biometrical methods in quantitative genetics analysis. Kalyani publishers, Ludhiana.

Tendulkar, S.K. 1994. Studies on line $\times$ tester analysis for development of F1 hybrids in tomato (Lycopersicon esculentum Mill.). M.Sc. (Agri.) Thesis, University of Agricultural Sciences, Dharwad.

Tieman, D.M., Zeigler, M., Schmelz, E.A., Taylor, M.G., Bliss, P. and Kirst, M. 2006. Identification of loci affecting flavour volatile emissions in tomato fruits. Journal of Experimental Botany, 57: 887-896.

\section{How to cite this article:}

Sunil Kumar M., A. K. Pal and Anil K. Singh. 2018. Studies on Heterosis and Inbreeding Depression for Quality Traits and Yield in Tomato (Solanum lycopersicum L.). Int.J.Curr.Microbiol.App.Sci. 7(06): 3682-3686. doi: https://doi.org/10.20546/ijcmas.2018.706.432 